\title{
Potassium supplementation, serum immunoreactive insulin concentrations and glucose tolerance in protein-energy malnutrition
}

\author{
By M. D. MANN, * DOROTHY J. BECKER, B. L. PIMSTONE† \\ AND J. D. L. HANSEN \\ Departments of Child Health and Medicine, University of Cape Town \\ Medical School, Observatory, Cape Town, South Africa \\ (Received ${ }_{25}$ February I974-Accepted I9 fuly 1974)
}

\begin{abstract}
I. The serum immunoreactive insulin (IRI) concentrations, and glucose disappearance rate-constants after intravenous glucose administration were measured on admission and during recovery in children suffering from protein-energy malnutrition (PEM).

2. A high potassium intake resulted in a considerable increase in the serum IRI leveis early in the treatment period. There was a definite relationship between potassium depletion and many measurements of insulin secretion.

3. The results are consistent with the hypothesis that impaired insulin release in children suffering from PEM is partly the result of potassium depletion.
\end{abstract}

Most children suffering from protein-energy malnutrition (PEM) have subnormal serum immunoreactive insulin (IRI) levels following a glucose load (Baig \& Edozien, I965; James $\&$ Coore, I970). The decreased response may be the result of an impairment in insulin release. Evidence for this is the frequently higher serum IRI levels after a glucagon-glucose stimulus than after a glucose stimulus alone (Becker, Pimstone, Hansen \& Hendricks, I97I) and the delayed response to oral glucose in many instances (Becker, Pimstone, Hansen, MacHutchon \& Drysdale, I972). Because potassium plays an important part in insulin secretion (Grodsky \& Bennett, I966; Hales \& Milner, 1968; Anderson, Herman \& Newcomer, 1969; Ashkar \& Katims, I970), and a severe $\mathrm{K}$ deficit is frequently found in PEM (Hansen, I956; Alleyne, Millward \& Scullard, 1970), we have investigated the effect of $\mathrm{K}$ supplementation on the serum IRI response to a glucose load. We also report its effect on glucose tolerance, as $\mathrm{K}$ depletion is one of the many causes of an abnormal glucose tolerance test (GTT) (Sagild, Andersen \& Andreasen, 1961; Conn, I965; Mondon, Burton, Grodsky \& Ishida, 1968).

\section{METHODS}

\section{Subjects and treatments}

Eighteen children aged $3^{-27}$ months were studied. All were under weight-for-age with oedema (kwashiorkor or marasmic kwashiorkor). All children except one had a serum albumin level of less than $30 \mathrm{~g} / \mathrm{l}$. They received a liquid lactose-free diet,

* Present address: Department of Paediatrics and Child Health, University of Rhodesia, Harari Central Hospital, PO Box S'T 494, Southerton, Salisbury, Rhodesia.

$\uparrow$ For reprints. 
supplying $3 \mathrm{mmol} \mathrm{K} / \mathrm{kg}$ body-weight per $\mathrm{d}$ from day $\mathrm{I}$ to day $\mathrm{r}_{3}$, day I being the day of admission. Twelve children (high $\mathrm{K}$-intake group) received an additional $\mathrm{I} 2 \mathrm{mmol}$ $\mathrm{K} / \mathrm{kg}$ body-weight per $\mathrm{d}$, as potassium chloride, from day 2 to day $\mathrm{I} 3$. The remaining six were unsupplemented (low $\mathrm{K}$-intake group). The serum $\mathrm{K}$ concentrations were checked each day.

Protein and fat were introduced into the diet on day 2, glucose being the sole energy source on day $\mathrm{I}$. The energy intakes $(\mathrm{kJ} / \mathrm{kg}$ body-weight per $\mathrm{d}$ ) were: approximately 200 on day I, I 75 from day 2 to day 4 and 240 from day 5 to day 8 inclusive. From day 2 to day 4 , and day 5 to day 8 , the diet supplied 0.3 and $0.6 \mathrm{~g}$ nitrogen $/ \mathrm{kg}$ bodyweight per $d$ respectively. Solid foods were introduced on day 9 and the $K$, energy and $\mathrm{N}$ intakes were increased by varying amounts depending on the quantity eaten. All the children received antibiotics, and iron and vitamin supplements.

The study was approved by the ethical committee of the Faculty of Medicine of the University of Cape Town. Informed written consent for the study was obtained from the parents in all instances. The children were nursed in the metabolic ward and kept under continuous expert surveillance.

The intravenous GTT was started between 08.00 and 09.00 hours after an $8-9 \mathrm{~h}$ fast, on day 2, day 5 and when the serum albumin had been greater than $30 \mathrm{~g} / \mathrm{l}$ for 2 weeks, i.e. on 'recovery'. Five of the high K-intake group and the six in the low Kintake group had an additional GTT on day 9 and day 13 . The blood glucose was checked with Dextrostix (Ames Co., PO Box 17479, Hillbrow, Johannesburg, South Africa) during the fast. Blood glucose and serum IRI concentrations were measured before and $5,20,45,60$ and $90 \mathrm{~min}$ after the intravenous injection of I $\mathrm{g}$ glucose $/ \mathrm{kg}$ body-weight as a solution $(0.25 \mathrm{~g} / \mathrm{ml})$ given over a 2 min period. The serum $\mathrm{K}$, total protein and albumin concentrations were measured in the fasting blood sample. Total body K (TBK) was measured immediately after each GTT. The volume of blood taken during each test did not exceed $7.5 \mathrm{ml}$ and the total volume taken during the study was less than $35 \mathrm{ml}$.

\section{Analytical methods}

Blood glucose concentrations were measured using a Technicon AutoAnalyzer (Technicon Instruments Corp., Tarrytown, New York) using a modification of the method described by Hoffman (1937). Serum IRI levels were estimated by a modification of the double-antibody method described by Morgan \& Lazarow (I963) using porcine insulin (Novo Research Institute, DK-2880, Bagsvaerd, Denmark) as standard and rabbit anti-porcine insulin serum (Wellcome Reagents Limited, Beckenham, Kent, England). Total serum protein was measured by the Biuret method (Wolfson, Cohn, Calvary \& Ichiba, 1948) and serum albumin by the method of Beckman Instrument Co. Inc. (1967) using a microzone electrophoresis apparatus (Beckman Instrument Co. Inc., Fullerton, California, USA). The serum K concentration was estimated using an atomic absorption spectrophotometer (Perkin-Elmer; model 303 ). A wholebody counter (Packard; Model 5107) was used to determine the TBK (Garrow, 1965.)

The glucose disappearance rate-constant $\left(k_{\mathrm{G}}\right)$ was calculated from the line of least squares when the log of the total blood glucose concentration was plotted $v$. time (Ikkos \& Luft, I957). The insulin:glucose (I:G) ratio was the ratio of the areas under 


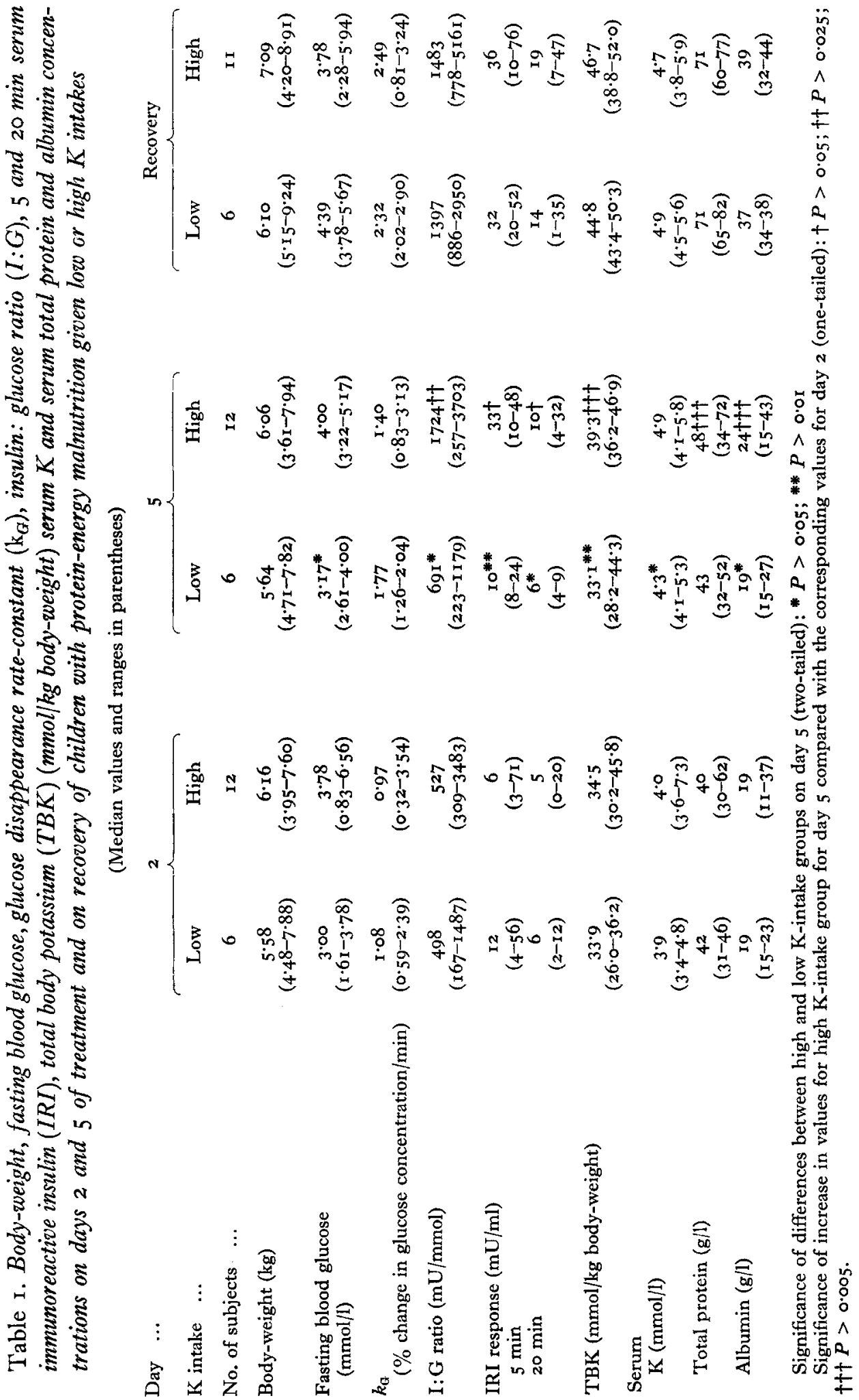


Table 2. Simple correlations between values for total body potassium (TBK) (mmollkg body-weight) and serum immunoreactive insulin (IRI) on day 2 of treatment for children with protein-energy malnutrition given low and high $K$ intakes and on day 5 of treatment for the high K-intake group
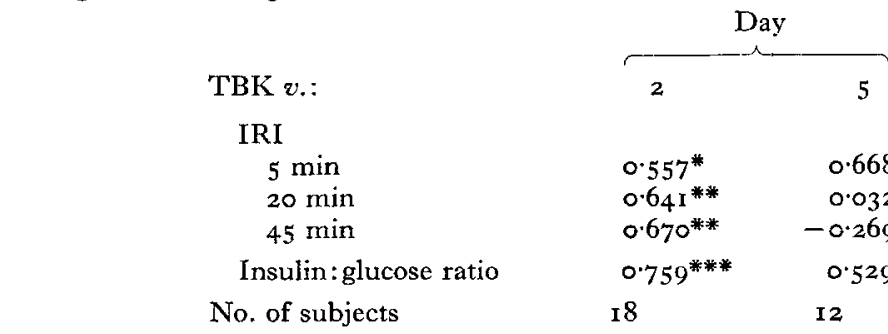

Statistical significance of correlation coefficients: $* P<0.05 ; * * P<0.01 ; * * * P<0.001$.

the respective curves after plotting the changes in blood glucose and serum insulin concentrations $v$. time.

The Mann-Whitney $U$ test was used to analyse between-group differences and the Wilcoxon matched-pairs signed-ranks test was used for within-group comparisons (Siegel, 1956). The standard Pearson product-moment (simple) correlation coefficients were calculated for the eighteen children on admission, the twelve children with high $\mathrm{K}$-intake on day 5 , and the seventeen children on 'recovery'. In instances when insulin concentrations could be correlated with two or more variables, which in turn could be correlated with each other, partial correlation coefficients were calculated. This gave the relationship between two variables when the effect of the others was held constant (Steel \& Torrie, I960).

\section{RESULTS}

\section{Comparison of low and high $\mathrm{K}$-intake groups}

The results obtained for the low and high K-intake groups were not significantly different from each other $(P>0 \cdot 1)$ on days 2,9 or 13 or on recovery. However, on day 5 there were appreciable differences between the two groups. In the high $\mathrm{K}$ intake group, the fasting blood glucose level, the IRI response to glucose at 5 and 20 $\mathrm{min}$, the area under the insulin curve, the $\mathrm{I}$ : $\mathrm{G}$ ratio, serum $\mathrm{K}$, TBK $(\mathrm{mmol} / \mathrm{kg}$ bodyweight) and albumin levels were higher than those of the low $\mathrm{K}$-intake group (Table r). The area under the glucose curve, total serum protein levels and IRI values at 45,60 and $90 \mathrm{~min}$ (not given in the table) were not significantly different $(P>0 \cdot 1)$ for the two groups.

Within-group comparison showed that the results for the low $\mathrm{K}$-intake group were the same on admission and day 5 . By contrast, in the high $\mathrm{K}$-intake group, there was a significant increase between day 2 and day 5 in the I:G ratio, 5 and 20 min IRI responses to glucose, TBK (mmol/kg body-weight), and the total protein and albumin concentrations. The improvement was such that the IRI responses of the high Kintake group on day 5 were not significantly different $(P>0 \cdot \mathrm{I})$ from those for this group on recovery. 
Table 3. Simple correlations between values for serum immunoreactive insulin (IRI), serum total protein and albumin on day 2 of treatment for eighteen children with protein-energy malnutrition given low and high $K$ intakes

\begin{tabular}{lll} 
IRI & \multicolumn{2}{c}{ Serum } \\
$5 \mathrm{~min}$ & $0.619^{*}$ & $0.786^{* * *}$ \\
$20 \mathrm{~min}$ & $0.713^{* * *}$ & $0.494^{*}$ \\
$45 \mathrm{~min}$ & $0.646^{* *}$ & $0.593^{* *}$ \\
Insulin:glucose ratio & $0.817^{* * *}$ & $0.57 \mathrm{I}^{*}$
\end{tabular}

Statistical significance of correlation coefficients: $* P<0.05$; $* * 0<0.0$; ** $P<0.001$.

Table 4. Simple correlations between glucose disappearance rate-constant $\left(\mathrm{k}_{G}\right)$ and total body potassium $(T B K)$, serum $K$, total protein, albumin and immunoreactive insulin (IRI) on day 2 of treatment for children with protein-energy malnutrition given low and high $K$ intakes and on day 5 of treatment for the high $K$-intake group

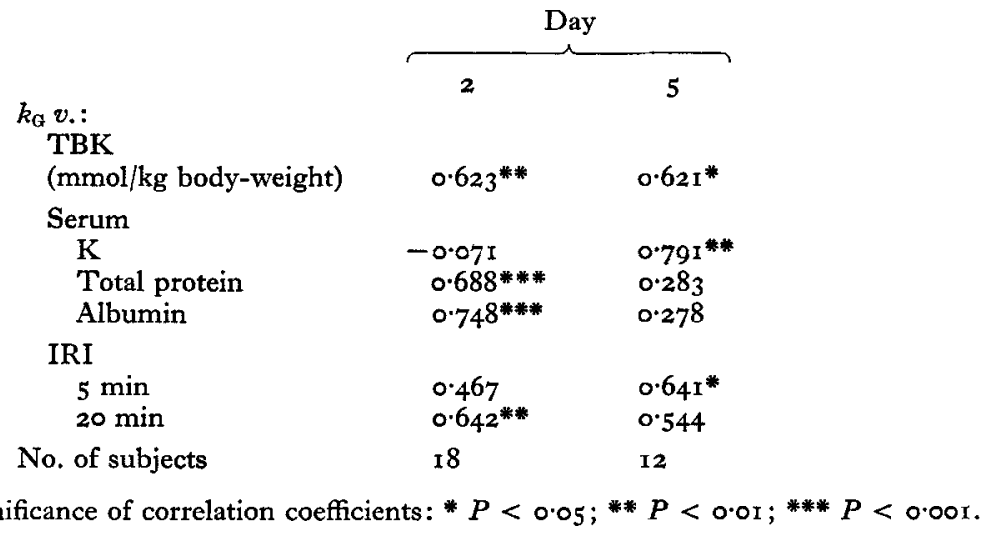

Insulin: the correlation with $T B K$, serum $K$, total protein and albumin

There was a correlation between the series of IRI values on day 2 and the TBK (mmol/kg body-weight), serum protein and albumin values (Tables 2 and 3 ). The partial correlation coefficients were not significant $(P>0.05)$. On day 5 , after a $\mathrm{K}$ supplement, there was a correlation between the $5 \mathrm{~min}$ IRI and I: $G$ ratio values and values for TBK (mmol/kg body-weight). There was no correlation between the insulin variables and serum $\mathrm{K}$ on day 2 or day $5(P>0.05)$.

No correlations were found on recovery $(P>0.05)$.

\section{$\mathrm{k}_{G}$ : the correlation with $T B K$, serum $K$, total protein, albumin and insulin}

There was a correlation between $k_{\mathrm{G}}$ values on day 2 , and TBK (mmol $/ \mathrm{kg}$ bodyweight), total serum protein and albumin (Table 4 ). There was also a correlation between the $20 \min k_{G}$ values and IRI response but not with the 5 min values. The only significant partial correlation was with serum albumin $(r 0.524, P<0.05)$. 
There was a correlation between $k_{G}$ values on day 5 and TBK ( $\mathrm{mmol} / \mathrm{kg}$ body-weight), serum $\mathrm{K}$ and $5 \mathrm{~min}$ IRI responses. The partial correlation with serum $\mathrm{K}$ was significant $(r 0.753, P<0.01)$. At no stage was there a relationship between $k_{G}$ and TBK (mmol). There were no correlations on recovery $(P>0.05)$.

\section{DISCUSSION}

The results for TBK suggest a moderate degree of $\mathrm{K}$ depletion in both groups of subjects on admission and little, if any, repletion between days 2 and 5 in the low $\mathrm{K}$-intake group. However, by day 5 there was a marked increase in TBK in the high K-intake group and in most cases repletion was almost complete (Alleyne et al. 1970). The fasting blood glucose concentrations, values for 5 and $20 \mathrm{~min}$ IRI response and $\mathrm{I}: \mathrm{G}$ ratios were low in the K-depleted children and rose on repletion. The striking difference in insulin responses between the low and high K-intake groups on day 5 relates to the $\mathrm{K}$ supplementation in the latter group. It appears that in many cases improvement of insulin secretion can already occur within $3 \mathrm{~d}$ of treatment.

The increase in the 5 and 20 min serum IRI response to glucose after $\mathrm{K}$ supplementation is consistent with the hypothesis that $\mathrm{K}$ is important in the release of stored insulin (Grodsky \& Bennett, I966; Grodsky \& Foresham, 1966; Hales \& Milner, r968) although changes in insulin space cannot be excluded. These results suggest that the impaired insulin release in PEM is due, at least in part, to the $\mathrm{K}$ depletion. The significant correlation coefficients between values for $\mathrm{TBK}$ ( $\mathrm{mmol} / \mathrm{kg}$ body-weight) and IRI response support this view. Peak IRI and TBK ( $\mathrm{mmol} / \mathrm{kg}$ body-weight) values correlated on day 2 and day 5 , the lowest values for serum IRI being found in those children who had the most severe $\mathrm{K}$ deficit. In contrast to the TBK (mmol $/ \mathrm{kg}$ bodyweight), the total serum proteins and albumin were related to serum IRI on day 2 only. This indicates that the relationship between IRI and TBK is not merely a reflexion of protein status. The rise in the area under the insulin curve and the $\mathrm{I}: \mathrm{G}$ ratio in the high $\mathrm{K}$-intake group is almost certainly due to the increase in the $5 \mathrm{~min}$ value for IRI, as the later values for IRI and the area under the glucose curve remained unchanged. This indicates an improvement in the early release of insulin by the $\beta$-cells after a glycaemic stimulus.

There are many possible reasons for the rise in the fasting blood glucose concentrations after $\mathrm{K}$ supplementation and this study does not give any indication of the pathways involved. The improved insulin secretion was not accompanied by parallel changes in glucose tolerance in the high $\mathrm{K}$-intake group. It is possible that the relatively low carbohydrate intake between days 2 and 5 masked changes in $k_{\mathrm{G}}$. Alleyne, Trust, Flores \& Robinson (1972) suggest that the decreased glucose tolerance in PEM may be due to a quantitative reduction in tissues which normally metabolize glucose. The $k_{\mathrm{G}}$ did not correlate with the TBK (mmol), a measure of lean body mass (LBM), but there was a correlation with TBK ( $\mathrm{mmol} / \mathrm{kg}$ body-weight) $(P<0.05)$. TBK (mmol/kg body-weight) can be regarded as a measure of LBM, but over the range of results on days 2 and 5 it reflects K status rather than LBM (Alleyne et al. I970). However, $\mathrm{K}$ status is probably not a major causative factor of the glucose 
intolerance. $k_{\mathrm{G}}$ did not improve with $\mathrm{K}$ supplementation and none of the partial correlations with TBK (mmol/kg body-weight) were significant.

This study suggests that $\mathrm{K}$ depletion may play an important role in the subnormal insulin response to an intravenous glucose load in PEM. $\mathrm{K}$ supplementation results in a rapid improvement in the IRI response and probably acts by facilitating insulin release. However, the abnormal IRI response cannot be due to the $\mathrm{K}$ deficit in all cases, as low insulin levels may persist long after $\mathrm{K}$ repletion is complete (James \& Coore, 1970; Becker et al. 197I). The causes of the impaired glucose tolerance are not clear but it does not appear that $\mathrm{K}$ depletion plays a major role.

\section{REFERENCES}

Alleyne, G. A. O., Millward, D. J. \& Scullard, G. H. (1970). J. Pediat. 76, 75.

Alleyne, G. A. O., Trust, P. M., Flores, H. \& Robinson, H. (1972). Br. F. Nutr. $27,585$.

Anderson, J. W., Herman, R. H. \& Newcomer, K. L. (1969). Am. f. clin. Nutr. 22, 1589.

Ashkar, F. S. \& Katims, R. B. (1970). Diabetes 19, 377.

Baig, H. A. \& Edozien, J. C. (1965). Lancet ii, 662.

Becker, D. J., Pimstone, B. L., Hansen, J. D. L. \& Hendricks, S. (1971). Diabetes 20, 542.

Becker, D. J., Pimstone, B. L., Hansen, J. D. L., MacHutchon, B. \& Drysdale, A. (I972). Am. F. clin. Nutr. 25, 499.

Beckman Instrument Co. Inc. (I967). Technical Manual RM-TB-oI I. Fullerton, California, USA: Beckman Instrument Co. Inc.

Conn, J. W. (1965). New Engl. F. Med. 273, II35.

Garrow, J. S. (1965). W. Indian med. 7. 14, 73.

Grodsky, G. M. \& Bennett, L. L. (1966). Diabetes 15,9 го.

Grodsky, G. M. \& Foresham, P. H. (1966). A. Rev. Physiol. 28, 347.

Hales, C. N. \& Milner, R. D. G. (1968). F. Physiol., Lond. 194, 725.

Hansen, J. D. L. (1956). S. Afr. F. Lab. clin. Med. 2, 206.

Hoffman, W. S. (1937). F. biol. Chem. r20, 5 I.

Ikkos, D. \& Luft, R. (1957). Acta endocr., Copenh. 25, 3 I 2.

James, W. P. T. \& Coore, H. G. (r970). Am. F. clin. Nutr. 23, 386.

Mondon, C. E., Burton, S. D., Grodsky, G. M. \& Ishida, T. (r968). Am. F. Physiol. $215,779$.

Morgan, C. R. \& Lazarow, A. (1963). Diabetes r2, I 5.

Sagild, U., Andersen, V. \& Andreasen, P. B. (196r). Acta med. scand. 169, 243.

Siegel, S. (1956). Non-parametric Statistics for the Behavioural Sciences. New York: McGraw-Hill.

Steel, R. G. D. \& Torrie, J. H. (1960). Principles and Procedures of Statistics. New York: McGraw-Hill.

Wolfson, W. Q., Cohn, G., Calvary, E. \& Ichiba, F. (1948). Am. F. clin. Path. r8, 723. 